\title{
'Whole-of-Nation' Approach and its Impacts: Case of the 2009 Swat Crisis in Pakistan
}

\section{Major General Syed Najeeb Ahmad}

\begin{abstract}
In May 2009, Pakistan faced a serious security dilemma when Taliban militants gained varying degrees of control in the Khyber Pakhtunkhwa provincial districts of Dir, Swat, Shangla, Malakand and Buner. The Government acted decisively to re-establish its writ. From May to October 2009, control of almost 6,500 square kilometers of area was regained from the Taliban. Following this kinetic phase, prolonged stabilisation efforts led to the return of normalcy. The tactful creation of political conditions by the country's leadership, despite historically problematic civil-military relations, provided the key to success. Built on trust, the 'whole-of-nation' approach comprising the civil government, military, civil administration, political parties and the people created unity of effort and command which proved successful.
\end{abstract}

Keywords: Swat, Malakand, 2009, Taliban, Whole-of-Nation,

Counterterrorism, Military Operation, Stabilisation.

\footnotetext{
* The author holds a doctorate in International Relations from the National Defence University (NDU), Islamabad, Pakistan. He can be reached at: ahmadnajeeb67@gmail.com.

@2019 by the Islamabad Policy Research Institute. IPRI Journal — XIX (1): 147-175. https://doi.org/10.31945/iprij.190107.
}

IPRI JOURNAL — WINTER 2019 


\section{Introduction}

$\mathrm{P}$ akistan's complex terrorism challenge has seen its ups and downs over the past decade and a half. In 2009, spawning from the erstwhile troubled Federally Administered Tribal Areas (FATA), radicalisation and extremism spread at an alarming speed into the peaceful and picturesque Swat area (Figure 1) of Khyber Pakhtunkhwa province of the country (Figure 2). ${ }^{1}$ This challenged the writ of the government in Swat and Malakand like never before, which led to a politically-backed military operation to stabilise the security situation. Fast forward to October 2018, the Khyber Pakhtunkhwa Government is now taking over administrative powers in Malakand from the Army after nine years. ${ }^{2}$ Apart from the peaceful situation, this is an indication of confidence in the institutional reforms by the provincial police to handle the current situation in Malakand. ${ }^{3}$

The violent upheaval which brought the Taliban to power in Swat and surrounding areas was a watershed moment in Pakistan's history. For those familiar with the country's political complexities, the swift response in the political, military, diplomatic and information domains against the Taliban in Swat was surprising. It was unique since all divisions and chasms subsided in favour of a unified approach. Built on trust, the 'whole-of-nation' approach comprising of the government, military, civil administration, political parties and the people created unity of effort, which effected victory.

${ }^{1}$ Khalid Aziz, "Drivers of Radicalism and Extremism in Pakistan," Criterion 11, no. 1 (2016): 79-128 (96, 117), http://www.criterion-quarterly.com/drivers-of-radicalism-andextremism-in-pakistan/.

2 Shahabullah Yousafzai, "Army Hands over Administrative Powers to Civil Authorities in Swat," Express Tribune, October 22, 2018, https://tribune.com.pk/story/1831403/1army-hands-administrative-powers-civil-authorities-swat/.

${ }^{3} \mathrm{CPO}$, Strategic Initiatives and Institutional Reforms in Khyber Pakhtunkhwa Police 2015-16 (Peshawar: Central Police Office, 2016), https://kppolice.gov.pk/thebook/book.pdf. 
'Whole-of-Nation' Approach and its Impacts: Case of the 2009 Swat Crisis in Pakistan

\section{Figure-1}

Swat District of Khyber Pakhtunkhwa Province

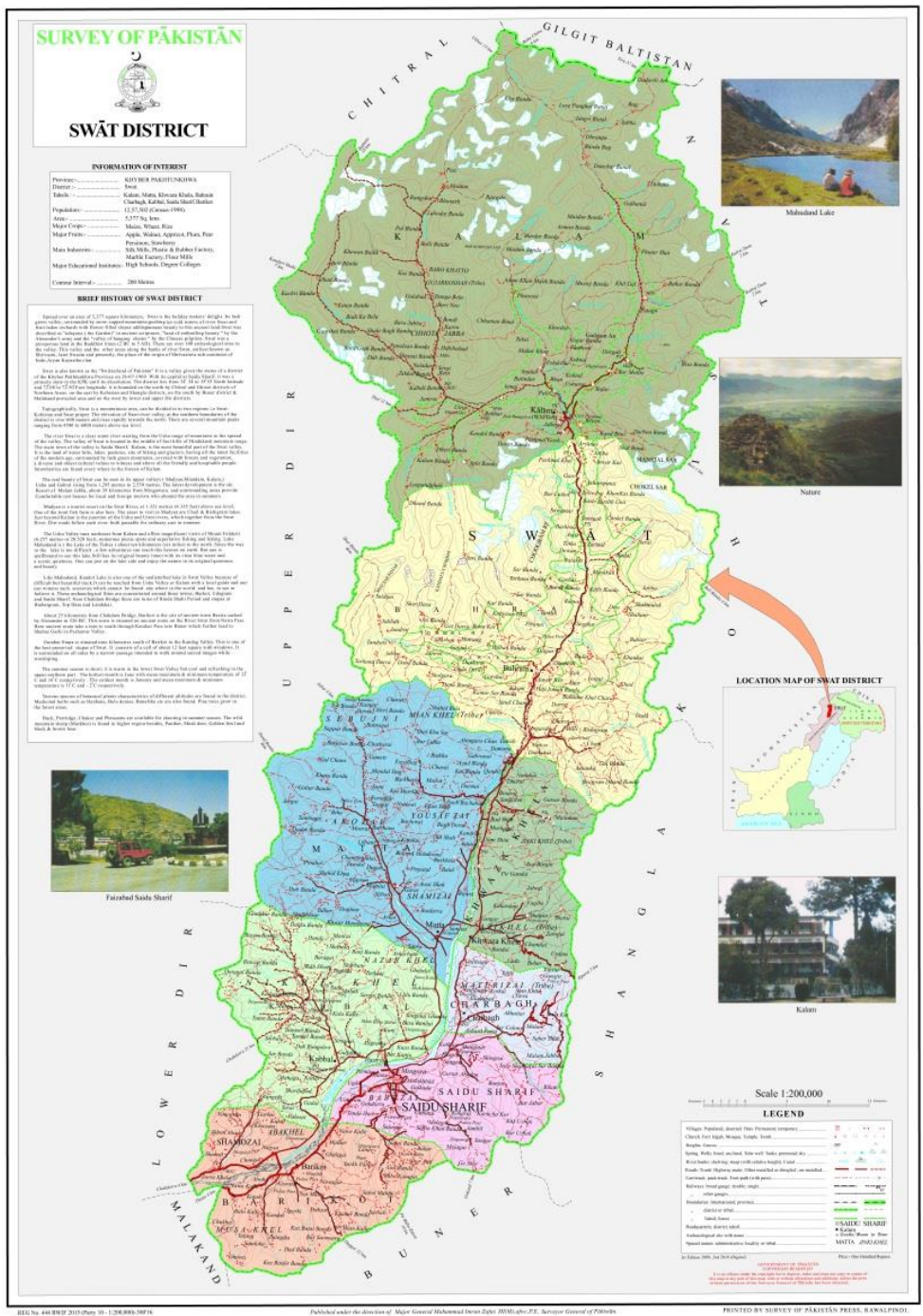

Courtesy: Survey of Pakistan. 
Figure-2

District Boundaries of Khyber Pakhtunkhwa Province

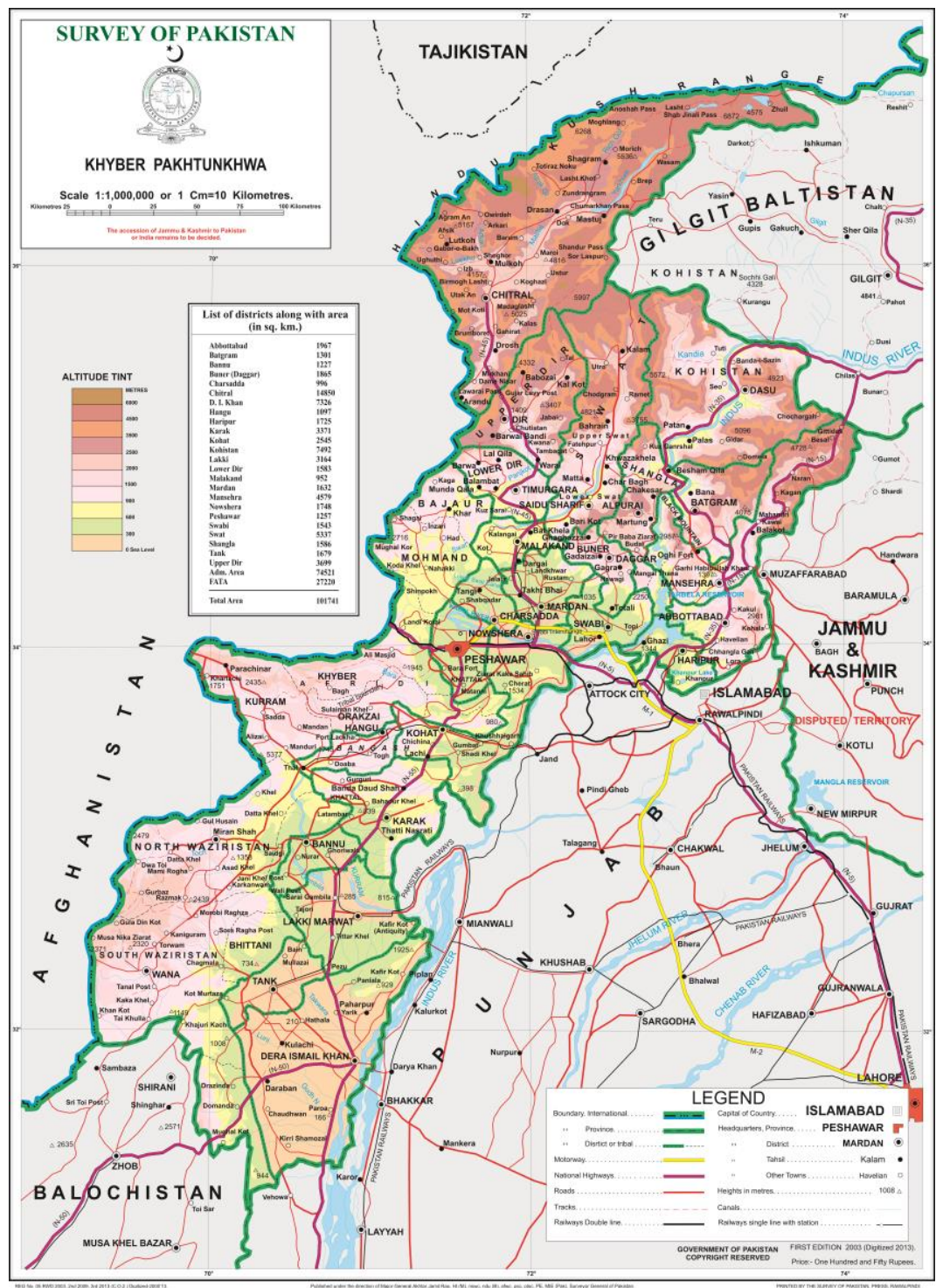

Courtesy: Survey of Pakistan. 
'Whole-of-Nation' Approach and its Impacts:

Case of the 2009 Swat Crisis in Pakistan

\section{What is 'Whole-of-Nation' Approach?}

An approach involving the people, civil administration, the Armed Forces, politicians, clergy, foreign interlocutors, media and donors, for dealing with a national security issue of critical proportion can be termed as a 'whole-of-nation' approach. In order to harmonise the aims and objectives of these diverse actors a set of conditions is required where the interests of every stakeholder are deemed to be secured. Building mutual trust in such a diverse matrix is the fundamental ingredient in these conditions, creation of which in the middle of ongoing terrorist activities, and then keeping it afloat during the dynamics of a swift counterterrorism operation is an existential challenge for the state. In such situations, concerns about the sincerity of each other's intentions are likely to come into play. Historical legacies of untrustworthiness, perceived by one stakeholder about the other(s), can lead to exacerbating apprehensions about each and every action. Intentions and capabilities of the state, its institutions, political parties, the media, and the foreign interlocutors come under acute focus. Alignment of institutional, public, national and even international interests, within a short period of decision-making in a critical national security situation, is necessary to achieve unity of effort, but it is not sufficient. It is vital to maintain such an alignment towards a unified objective in spite of the challenges faced during the execution phase. Trust-building and trust retention, thus, symbolise the conditions under which the 'whole-of-nation' approach functions.

The United Nations (UN) 'Global Counter-Terrorism Strategy', adopted by consensus in 2006, is constructed around four pillars: addressing the conditions conducive to the spread of terrorism; preventing and combatting terrorism; building states' capacity and strengthening the role of United Nations; and ensuring human rights and the rule of law. ${ }^{4}$ Ten years later, the UN 'Global Counter-Terrorism Strategy Review', adopted by the General Assembly on July 1, 2016, addressed the many facets of terrorism and numerous counterterrorism strategies, but did not

${ }^{4}$ United Nations Office of Counter-Terrorism, "UN Global Counter-Terrorism Strategy," September 8, 2016, https://www.un.org/counterterrorism/ctitf/en/un-global-counterterrorism-strategy.

IPRI JOURNAL — WINTER 2019 
take into account the necessity of considering a 'whole-of-nation' approach. ${ }^{5}$ Similarly, INTERPOL's 'Global Counter-Terrorism Strategy' 2017 outlines five 'action streams to prevent and disrupt terrorist activities,' including identification, travel and mobility, online presence, weapons and material, and finances without mentioning the need of galvanising the nation for countering the spread of terrorism. ${ }^{6}$ In Sandler's elaborate introduction to 'Terrorism and Counterterrorism,' a summary of pertinent articles by Oxford Economic Papers, there is no mention of a 'whole-of-nation' strategic approach either. ${ }^{7}$ Even Pakistan's 'National Internal Security Policy: 2014-18' is devoid of any lesson drawn from the Swat victory relevant to this approach. ${ }^{8}$ The subsequent sections provide an analysis of the conditions required for achieving unity of effort or the 'whole-of-nation' approach, and its impact on Swat in 2009, in order to fill this gap in the literature.

\section{Crisis in Swat: An Overview}

Pakistan had been facing a complex security situation along its western borders for nearly a decade after $9 / 11$, by the time Swat crisis hit the country as a grave national security threat in early 2009. Spreading out from the tribal regions bordering Afghanistan, militancy and religious extremism reached Swat, undermining writ of the Government there like never before. Swat is located in Malakand Division of Khyber Pakhuntunkhwa province in North West of Pakistan. It is bounded by

5 United Nations General Assembly, Resolution A/RES/70/291, "The United Nations Global Counter-Terrorism Strategy Review," July 19, 2016, http://www.un.org/en/ga/search/view_doc.asp?symbol=A/RES/70/291.

6 IGS, "Global Counter-Terrorism Strategy" (Lyon: Interpol General Secretariat, February 2017),

https://www.google.com/url?sa=t\&rct=j\&q=\&esrc=s\&source=web\&cd=17\&cad=rja\&u act=8\&ved=0ahUKEwi_6PyQ_frYAhWBIVAKHT27CjoQFgh-

MBA\&url=https $\% 3 \mathrm{~A} \% 2 \mathrm{~F} \% 2 \mathrm{Fwww}$.interpol.int $\% 2 \mathrm{Fen} \% 2 \mathrm{FMedia} \% 2 \mathrm{FFiles} \% 2 \mathrm{FCrime}-$ areas $\% 2 \mathrm{FTerrorism} \% 2 \mathrm{FCounter-Terrorism} \% 2 \mathrm{FGlobal}-\mathrm{Counter}$-Terrorism-StrategySummary\%2F\&usg=AOvVaw2UICA8yu7h5Lcz1BldVKaE.

7 Todd Sandler, "Terrorism and Counterterrorism: An Overview," Oxford Economic Papers 67, no. 1 (2015): 1-20, https://doi.org/10.1093/oep/gpu039.

8 Ministry of Interior, GoP, National Internal Security Policy: 2014-18 (Government of Pakistan, 2014), http://ankltd.com/Download_s/Rules/NISP.pdf. 
'Whole-of-Nation' Approach and its Impacts:

Case of the 2009 Swat Crisis in Pakistan

Karakorum Highway in the East leading to the picturesque GilgitBaltistan region, and the troubled Kunar, Nooristan provinces of Afghanistan in the West. The entire population of Swat was around 1.7 million during that period. The people of the region share a common identity and history, regardless of their ethnicity or tribal background. The Swat Valley is a popular vacation destination known for its great natural beauty, pristine rivers, mesmerising landscape, ski resorts, hospitable people and diverse fruits. Average height of mountains forming these valleys is above $10,000 \mathrm{ft}$. It is in no way a remote part of the tribal hinterland, sitting only $250 \mathrm{~km}$ from the capital of Pakistan, Islamabad with a good road connection.

Since 1990, the people of Swat had been demanding implementation of Shariah (Islamic) Laws in the area. 2001-07 was the period when the rise of militancy in Swat took place under the same garb. In November 2007, the military moved into Swat to control this militancy and terrorism, but with a low footprint. During April 2008, the Government of Pakistan (GoP) announced a Counter Terrorism Strategy based on the principles of Deterrence, Development and Dialogue, ${ }^{9}$ on which, in September 2008, certain selective military actions were taken against the miscreants. During October 2008 to March 2009, the situation worsened as law and order broke down completely. The police force suffered heavy casualties and several police stations were destroyed, while a few were captured by the terrorists.

\section{'Whole-of-Nation' Approach in Action}

\section{Building National Consensus and Unity}

The Tehreek-e-Nafaz-e-Shariat-e-Mohammadi (TNSM [Movement for the Enforcement of Islamic Law])-led extremism was ongoing in Swat since the early ' 90 s, which gradually adopted a more militant posture in the

\footnotetext{
${ }^{9}$ Raza Rumi, Charting Pakistan's Internal Security Policy, report no. 368 (Washington, D.C.: United States Institute of Peace, 2015), https://www.usip.org/sites/default/files/SR368-Charting-Pakistans-Internal-SecurityPolicy.pdf.
} 
wake of 9/11, and expanded to include Tehreek-e-Taliban Pakistan (TTP) in its folds, posing a strategic challenge to the GoP by 2007-08. ${ }^{10}$

The Zardari-led Pakistan People's Party (PPP) government in the Centre, and the Hoti-led Awami National Party (ANP) government in Khyber Pakhtunkhwa province, elected in 2008 on a progressive and prodemocracy mandate, wanted to resolve the militancy challenge in Swat by way of negotiations. After a contentious negotiation process, the provincial and federal governments reached a political agreement in April 2009, by virtue of which the TNSM was required to, inter alia, denounce militancy, accept the constitutional mandate of the Government, and not obstruct female education and employment. In return, the Government would implement a Nizam-e-Adl (System of Justice) legislation empowering religious courts to provide speedy justice to the local population, a long outstanding popular demand exploited by local religious radicals. However, Sufi Muhammad, the leader of TNSM failed to implement the accord due to his lack of control over the cadres who were not ready to surrender their newfound empowerment, which they had acquired by terrorising their wealthy landlords, under the garb of religion. Moreover, he also reneged on his promise to accept the State of Pakistan's legal and constitutional standing within which the Government had agreed to be flexible in adopting the local implementation of Islamic law. ${ }^{11} \mathrm{He}$ rejected democracy and Pakistan's constitution as un-Islamic, and hence, unacceptable as the basis of any accord. ${ }^{12}$

TNSM's recalcitrance reflected its political confidence emanating from the favourable public support in Swat Valley to this violent political movement. Motivated by the fiery rhetoric of Fazlullah and Sufi Muhammad, the local population visualised a model of justice and fair play under the future Shariah rule promised by these clerics. The federal

${ }^{10}$ Syed Nazre Hyder, Gulbaz Ali Khan, Kanwar Muhammad Javed Iqbal, Muhammad Tahir and Maqsood Ahmad, Effects of Militancy and Impact Trends of Rehabilitation in Malakand Division, report (Islamabad: Sustainable Development Policy Institute, 2011), https://www.sdpi.org/publications/files/Militancy\%20Report.pdf.

${ }^{11}$ Nasir Iqbal, "Sufi's Rejection of Superior Courts does not Surprise Experts," Dawn, April 21, 2009, http://www.dawn.com/news/458898.

${ }^{12}$ Rohan Gunaratna and Khuram Iqbal, Pakistan: Terrorism Ground Zero (London: Reaktion Books, 2010), 76-77. 
'Whole-of-Nation' Approach and its Impacts:

Case of the 2009 Swat Crisis in Pakistan

and provincial governments, hopeful of the success of the peace accord, were taken aback when the militants, instead of reconciling, actually dug in and expanded their armed incursion from Swat and Malakand districts to the neighbouring district of Buner under the umbrella terrorist organisation of TTP. This organisation was formed in December 2007 in the wake of a watershed fight against Red Mosque terrorists in Islamabad by Pakistan Army in July 2007, which subsequently led to a violent blowback. The Swat Valley was the first, and thankfully the last settled region outside of erstwhile FATA, to fall completely into the hands of TTP. $^{13}$

\section{Warranting the Military Option}

The influence of terrorist agendas in the Swat area weakened state control over the course of ten years. Collapse of state institutions and the security apparatus followed a massive destruction of schools, hospitals and communication infrastructure that took place as a result of terrorist activities. Public executions and floggings were the order of the day for those resisting the Taliban. In April 2009 alone, 18 terrorist attacks were carried out in the Malakand area, eight of them targeting the Army and police. ${ }^{14}$ The Taliban, believed to be having 7000 active fighters in Swat, were aggressively engaged by the military. ${ }^{15}$ The ground forces operation was augmented using artillery and air support, with the objective to defeat the terrorists, reclaim territorial control, and restore the lost confidence of the people in the State. Since offensive military forces were not present in the area, military formations were moved to Swat on short notice from

\footnotetext{
${ }^{13}$ William Avis, Drivers of Conflict in the Swat Valley, Pakistan, report (Birmingham: GSDRC Helpdesk Research, 2016), 4, https://assets.publishing.service.gov.uk/media/58592f2fed915d0aeb0000e0/HDQ1398.p df.

${ }^{14}$ Manzoor Khan Afridi and Musab Yousufi, "Military Operation in Malakand Division Pakistan: Causes and Implications," Asian Journal of Social Sciences \& Humanities 3, no. 3 (2014): 3 .

${ }^{15}$ Bill Roggio, "Pakistani Army to 'Eliminate' the Taliban in Swat: Prime Minister Gilani," FDD's Long War Journal, May 7, 2009, http://www.longwarjournal.org/archives/2009/05/pakistan_army_to_eli.php.
}

IPRI JOURNAL — WINTER 2019 
other parts of the country. An envelopment was planned to capture sensitive areas and deny any sanctuary to the Taliban in a swift and decisive maneuver. The Army expected guerilla tactics by the Taliban including ambush, raid, use of snipers, booby traps, Improvised Explosive Devices (IED), and kidnapping for ransom. Washington Post reported on May 24, 2009:

The pace of the operation will be painfully slow. So be patient. But the operation has started, and, God willing, we are going to take it to a logical conclusion,' said Maj. Gen Athar Abbas, a military spokesman...the Taliban is thought to have dug into positions in Mingora, and any effort to win back the densely packed city is likely to be long and bloody. Abbas said troops would conduct house-to-house searches and had been warned about suicide attacks. ${ }^{16}$

Public opinion was the principal factor behind this decisive step taken by the Government. The government of Muttahida Majlis-e-Amal (MMA) in Khyber Pakhtunkhwa kept on underplaying the threat of TTP and TNSM in Swat from 2002 till 2007, proclaiming insufficient public support for a decisive operation as the reason of their inaction. When the PPP-led government decided to go into Swat in May 2009, the citizenry overwhelmingly supported the initiative. A key element that turned the public against the militants in Swat was the video of a girl's public flogging in Swat by the TTP. ${ }^{17}$ Then-Prime Minister Yousuf Raza Gilani called the military operation 'a fight for the survival of the country.' ${ }^{18}$ A successfully constructed narrative, of exceptional

\footnotetext{
${ }^{16}$ Griff Witte, "Pakistan Intensifies Effort with Thrust into Swat's Main City," Washington Post, May 24, 2009, http://www.washingtonpost.com/wpdyn/content/article/2009/05/23/AR2009052301775.html.

${ }^{17}$ Issam Ahmed, "Outrage over Taliban Flogging of Pakistani Girl could Threaten Peace Deal," Christian Science Monitor, April 5, 2009, https://www.csmonitor.com/World/Asia-South-Central/2009/0405/p90s01-wosc.html.

${ }^{18}$ Susanne Koelbl, Sohail Nasir, and Shazada Zulfiqar, "Pakistan's Anti-Taliban Offensive: The Fight for the Swat Valley," Spiegel Online, May 20, 2009, http://www.spiegel.de/international/world/pakistan-s-anti-taliban-offensive-the-fightfor-the-swat-valley-a-625961.html.
} 
'Whole-of-Nation' Approach and its Impacts:

Case of the 2009 Swat Crisis in Pakistan

circumstances warranting exceptional means, enabled the formation of legitimacy for the use of force:

The Pakistani Army's chief, General Ashfaq Kayani, remarked that the Taliban not be allowed 'to impose their way of life on the civil society of Pakistan.' Within a matter of days following the speech, the Army opened a campaign to remove the insurgents from Buner and Lower Dir. The public and media applauded its actions, and nearly the entire political establishment endorsed a sustained offensive against the Taliban in an All-Parties Conference. ${ }^{19}$

\section{Narrative Building}

The significance of narratives in asymmetrical warfare has been a subject of significant academic debate because of the profound impact that they have upon the social space which the terrorists crave for recognition of their cause. Since Pakistan's leading role in the United States' war against the Soviet Union in Afghanistan, narratives seeking recognition of Jihad (holy war) as a sublime virtue for Muslims in support of other Muslim brothers in need had become popular. ${ }^{20}$ The Soviet Union's defeat seemed to vindicate the Afghan Jihad narrative. After 9/11, extremist narratives sought revenge from the US and their cronies for the 'guiles, injustices and atrocities' committed against Muslims across the world. Apart from the erstwhile FATA, Swat proved to be a fertile ground for such narratives as is evident from the early forays of TNSM. This fertility could only be countered in the same coin, i.e., propagating an alternative, indigenously evolved narrative, with better appeal and resonance amongst those 'aggrieved' people who had come to see the world through the extremist

\footnotetext{
${ }^{19}$ Marvin G. Weinbaum, "Hard Choices in Countering Insurgency and Terrorism along Pakistan's North-West Frontier," Journal of International Affairs 63, no. 1 (2009): 73 88 (79).

${ }^{20}$ Fatima Sajjad, "Countering Extremists' Narrative in Pakistan," NDU Journal XXIX (2015): 75-94.
} 
lens. ${ }^{21}$ For any effort at countering the extremist narratives to succeed, first the storyline of those inimical narratives needs to be understood. Haider argued that Taliban's attempt at mainstreaming extremism in Pakistan was based on two narrative streams: groups that regard the Pakistani state as an enemy of Islam for having sided with the US in the invasion of Afghanistan; alongside these groups are the ones waving the banner of an Islamic state and a return to religious purity as the antidote to Pakistani state's inability to provide basic services, tackle economic inequities, and deliver justice. Swat is a prime example where a longstanding movement for the implementation of Shariah law, fuelled by anger at a broken system of justice and an exploitative landed class, violently boiled over with TTP support. ${ }^{22}$

On its part, the state built nationwide consensus to legitimise the offensive in the backdrop of the Taliban's competing argument, i.e., 'The Army is fighting against our own people.' The state presented the Taliban image as ruthless terrorists, barbaric extremists, anti-Islam, anti-human rights fascists, and backward anti-development ultra-conservatives. ${ }^{23}$ The depiction was generally localised and supported by certain events interpreted to fit in the anti-Taliban narrative. The Taliban-image was not only construed in relation to the events that preceded the military offensive, but also during the operation. It weaved along issues which dealt with the common knowledge of the general population, and on which already some sort of consensus existed. A clear depiction of the 'enemy' identity was essential because without it, the state would seem to be fighting against its 'own people' at the behest of the US. The main contours of the State's information campaign included:

${ }^{21}$ Amil Khan, Pakistan and the Narratives of Extremism, report no. 327 (Washington, D.C.: United States Institute of Peace, 2013),

http://humanitarianlibrary.org/sites/default/files/2014/02/SR327-Pakistan-and-theNarratives-of-Extremism_0.pdf.

${ }^{22}$ Ziad Haider, "Ideologically Adrift," in Pakistan Beyond the 'Crisis State', ed. Maleeha Lodhi (Karachi: Oxford University Press, 2011), 113-30.

${ }^{23}$ Shamil Shams, "The Clash of Narratives: Swat Military Operation against the Taliban" (paper no.120, Sustainable Development Policy Institute, Islamabad, 2011), 12, https://www.sdpi.org/publications/files/W-120.pdf. 
'Whole-of-Nation' Approach and its Impacts:

Case of the 2009 Swat Crisis in Pakistan

- Taliban are 'extremists', 'terrorists' not 'Islamists'.

- National security is under grave threat.

- The Taliban's ruthless and inhuman regime deserves decisive military intervention.

- Such exceptional means of redressal were not the first, rather the last option.

On the other hand, the Taliban in their propaganda campaign, interviews and statements, highlighted the alleged pro-Western foreign and security policies of the GoP, claiming that the Government and Army had consistently acted contrary to the interests of the Muslim Ummah (Muslim brotherhood) and its Mujahideen (holy warriors). ${ }^{24}$ Leaders and spokesmen of TTP publicly identified two broad aims - to end foreign occupation of Afghanistan, for which the movement acted in support of the Afghan Taliban Movement; and to establish a Shariah-based state in Pakistan. ${ }^{25}$

\section{Obtaining Domestic and International Legitimacy}

The exceptional means of redressal against the TTP's terrorism in Swat, however, were not all about use of force. The provincial government of North West Frontier Province (NWFP), as the Khyber Pakhtunkhwa province was then called, devised a comprehensive strategy to counter the extremist militancy and make Malakand more stable and prosperous. The strategy was prepared with the help of the UK's Stability, Reconstruction and Peacebuilding offices, along with the US Agency for International Development (USAID) experts, working with the provincial government from July - August 2009, with substantive financial support from the US, UK, International Financial Institutions (IFIs), Japan, Sweden, and other bilateral partners. The planning exercise was hosted by the Provincial

\footnotetext{
${ }^{24}$ Michael Semple, "The Pakistan Taliban Movement: An Appraisal” (paper, Barcelona Centre for International Affairs, Barcelona, 2014), 6, https://www.cidob.org/es/content/download/42779/627346/file/MICHAEL. ${ }^{25}$ Ibid.
} 
Reconstruction, Rehabilitation, and Settlement Authority (PaRRSA), a local body created in June to lead the effort. ${ }^{26}$

Implementation of the comprehensive strategy was dependent upon enabling conditions, termed as 'key assumptions': immediate assistance to the provincial government; improved security environment; local support for the government's programme; sustained political will; effective federal - provincial relationship; sustained cross-political party support; sustained international help; and no outbreak of fresh violence. ${ }^{27}$ In hindsight, local support for the Government's programme of stabilisation and socioeconomic development was perhaps the most significant enabler that sustained the legitimacy of the stabilisation effort spread over ten years. ${ }^{28}$

Sustaining this broader local support, despite undercurrents of dissatisfaction amongst the affected populace, was a significant challenge for the Army and the provincial administration alike. Results of responses to certain pointed questions about the Government's strategy in Malakand in a research conducted by Afridi and Yousafi highlighted the difficulties in this regard given that the 'military operation had positive and negative impacts on the people.' Notwithstanding the sampling handicaps of their research, 78 per cent agreed that the Government's negligence was responsible for the military operation; 85 per cent of the respondents faced damages during the military operation; 86 per cent believed that the military operations affected the lives of innocent people. The researchers concluded:

${ }^{26}$ Provincial Relief, Rehabilitation, and Settlement Authority, GoP, Malakand Comprehensive Stabilization and Socio-Economic Strategy 2009-14 (Government of Pakistan, 2009).

${ }^{27}$ Ibid.

${ }^{28}$ Stabilisation or stability operations in a troubled area entail actions more comprehensive than 'reconstruction and rehabilitation.' Curbing miscreants' liberty of action through effective intelligence operations, restoring people's confidence in the state security apparatus by show of force, creating deterrence against the miscreants' threat vectors, helping the people restart their lives by invigorating socioeconomic opportunities, restoring infrastructure damaged during the fighting, tactical coordination with neighbouring countries to prevent infiltration, creating an enabling environment for the civilian administration to function, image building, and providing financial compensation to the war-affected people are some of the facets of stabilisation. 
People of different areas have different perceptions about the military operation and extremism in the region... Lack of good governance weakens local loyalty for the government, like emergence and illegal activities of TNSM became causes of militancy in the region. The FM broadcasting was used to change the mind and attitude of the people towards social instability and extremism. ${ }^{29}$

The counter-argument is Pakistan Army's perspective on conducting the operations with full public support in Swat. In their view, as gathered during interaction with officers who participated in the operations, local support was possible because the terrorists turned the population against themselves by their extremist actions. They had promised improved governance and rule of law. However, the way in which they implemented this promise was unexpected and unacceptable, which prompted the people to ask for help from the Government. People's support was also garnered by jamming the Taliban FM radio networks spreading propaganda, and by giving the local media access to the affected areas to highlight the Taliban's atrocities. Collateral damage was minimised by exercising extreme care in the operations, and avoiding artillery and air engagements. Supporting the political process till it failed to deliver, and swift return to civil control, also empowered the people, ultimately strengthening legitimacy of the counterterrorism and stability operations.

Numerous foreign aid, developmental and assistance programmes were also implemented for the economic revival of the people of Malakand, whose livelihood was affected not only by the terrorism and counterterrorism operations, but also by the massive floods in 2010 and 2011. Approximately, 1250 miles of roads, 170 bridges, 700 educational and 150 health facilities, and 158 government buildings were completely destroyed in the calamities. Community resilience projects, funded by friendly countries, promoted peace-building and rehabilitation by restoring roads, water channels, street pavements, small bridges and

${ }^{29}$ Afridi and Yousufi, "Military Operation in Malakand Division Pakistan: Causes and Implications."

IPRI JOURNAL — WINTER 2019 
culverts. ${ }^{30}$ Acceptability of the stabilisation effort also increased through such developmental projects.

\section{IDPs Management}

Efficient management of the Internally Displaced Persons (IDPs) became a prime indicator in the public eyes linked with the legitimacy of the military and the stability operations. Smooth and scandal-free handling of this huge task was the Government's foremost priority. IDP relief camps were established in carefully selected areas in proximity to Malakand, in Mardan, Charsadda, Nowshera, Swabi, Peshawar and some districts further south like Tank and Dera Ismail Khan. Facilitation and assistance of persons who stayed behind in their native areas, despite the dangers of ongoing operations, was another delicate responsibility reposed with those Army units undertaking the clearance operations in the terrorist-infested areas. The hasty return of some of the displaced persons, seeking succor in their abandoned lands, homes and orchards was contrary to a planned and organised return, which the authorities had desired.

To prevent terrorists from hiding amongst the IDPs in camps, an important triangular responsibility was managed by the civil and military authorities, i.e., simultaneous and timely provision of security (from outside terrorist attacks), intelligence (about presence of any militants, sympathisers or facilitators amongst the IDPs) and relief measures (such as displacement grant of USD 325, food, healthcare, hygiene, transportation to and from the affected areas). A return package including cash grant of USD 325, free medical examination and medicines, one month food rations, non-food items and construction tools for property rebuilding were provided. In certain vulnerable cases, vocational training facilities were also arranged. The return was based on four principles. It

\footnotetext{
${ }^{30}$ United Nations Development Programme in Pakistan, "Fostering Resilient Communities in Khyber Pakhtunkhwa," accessed January 22, 2019,

http://www.pk.undp.org/content/pakistan/en/home/operations/projects/crisis_prevention _and_recovery/project_sample.html.
} 
'Whole-of-Nation' Approach and its Impacts:

Case of the 2009 Swat Crisis in Pakistan

had to be informed, voluntary, safe and assisted. If someone chose to stay back, his or her relief assistance continued. ${ }^{31}$

\section{Effects of Conflict Spillover}

The mobilisation of public opinion, which led to the swift employment of a mix of coercive and non-coercive means to control the spiraling situation in Swat, could not keep momentum to pursue the militants in their sanctuaries elsewhere. It was a setback for the stabilisation effort at the national level. For example, a stable Swat but an unstable Waziristan would not have been a desirable strategic outcome. The reasons were manifold and contentious. Lack of political will on part of the ruling political parties in the centre and Khyber Pakhtunkhwa province to utilise the antagonistic public sentiment towards terrorism and translate it into a workable strategy, was the major reason of not expanding the counterterrorism effort beyond Swat. Another military action did take place in South Waziristan area after the Swat operation, called Operation Rah-e-Nijat (Path of Riddance), but its gains were also not consolidated further due to operational overstretch of the Army. The fleeing terrorists could not be pursued into North Waziristan and Khyber Agency. The 'balloon effect', i.e., escaping of terrorists from one sanctuary to the other upon application of pressure, could not be controlled. Faiz-Ur-Rehman, et al., concluded that 'any counterinsurgency strategy that lacks strong political support and measures to debilitate militant networks may not be able to curtail violence. ${ }^{32}$

The narrative was also significantly affected by external actors like the US, India and Afghanistan. The public was skeptical about the US intentions of actually helping Pakistan fight its internal war against terrorism. The infamous US mantra of 'do more' for Pakistan became an

\footnotetext{
${ }^{31}$ Nadeem Ahmed, "Coin in Peace-Building: Case Study of the 2009 Malakand Operation," Prism 2, no. 4 (2011): 125-138, https://www.ciaonet.org/attachments/19705/uploads.

${ }^{32}$ Faiz-Ur-Rehman, Muhammad Nasir, and Muhammad Shahbaz, "What Have We Learned? Assessing the Effectiveness of Counterterrorism Strategies in Pakistan," Economic Modelling 64 (2017): 487-495, https://doi.org/10.1016/j.econmod.2017.02.028.
} 
anathema that fuelled anti-Americanism and complicated the situation, helping the terrorists to find sympathetic ground within public opinion. The populace was afraid of a repeat of the kind of post-Red Mosque 2007 terrorism blowback, and hence ambivalent in their wholehearted antiterrorism support. The North Atlantic Treaty Organization (NATO) 'occupation' forces in Afghanistan were projected by the radicals as the root cause of all problems, and right-wing political parties cashed in on this rhetoric, further disabling any tendency towards a unified national stance against Taliban terrorism. ${ }^{33}$

\section{Impact of Military Constraints and Gains}

The military operation was constrained by the limited time available for evacuation of the population, and the necessity of confidentiality which frustrated the evacuees, leaving many in the lurch as the fighting began. At the time, the long-term impact of their miseries, resulting from migration to safety and ensuing war damage to infrastructure and property, was unclear to the displaced masses. After the main offensive was over in about three months, the militants' leadership fled to Afghanistan, while many of their foot soldiers managed to melt into the Provincially Administered Tribal Areas (PATA) and urban centres, countrywide. Much later, the shooting of Malala Yousafzai on October 9, 2012 along with two of her friends in Mingora, the capital of Swat District, and some other sporadic terrorism incidents around the same period, highlighted the challenges of stabilising the area due to presence of incognito Taliban and their sympathisers within the population.

The discussion around structural orientation of the Pakistan Army, and the financial support being provided by the US to Pakistan also impacted the stabilisation effort. The structural and doctrinal orientation of the military largely remained conventional due to the traditional challenge from India, which the US keenly observed as detrimental to the larger 'fight against terror'. However, soon after Swat was re-taken, USD 7.5 billion in non-security assistance was pledged under the Kerry-Lugar

${ }^{33}$ Moeed Yusuf, ed., Pakistan's Counterterrorism Challenge (Washington, D.C.: United States Institute of Peace, 2014), 37. 
'Whole-of-Nation' Approach and its Impacts:

Case of the 2009 Swat Crisis in Pakistan

Bill, 'in the most significant rebalancing of the US-Pakistan relationship to date away from its formerly near-exclusive focus on security matters. ${ }^{, 34}$

The outcome of the US' financial assistance programme and Pakistan's willingness to decisively counter the menace of terrorism was put in doubt by the West. Different reasons were cited for those doubts. The Pakistan Army's capacity to clear and hold areas, while winning and sustaining support of the locals, in many diverse terrorism-ridden areas of the country simultaneously, was one. The US blamed Pakistan for partisanship in dealing with terrorist organisations according to their aims and objectives, ignoring the ones operating against Indian and US interests, and only going after the ones hurting Pakistan. The US stressed that the domestic narrative, needed to sustain the momentum required for going after terrorists by the Armed Forces and the Law Enforcement Agencies (LEAs), was wanting, since public opinion remained divided about whether it was Pakistan's war or a proxy war of the US. Most importantly, the GoP's inability to have a mechanism for developing an integrated and comprehensive antiterrorism effort was seen by the US as a fundamental weakness. ${ }^{35}$

In six months, from May to October 2009, control of almost 4,000 square miles of area was regained from direct control of the TTP with 400 soldiers martyred and 3500 militants killed. At the same time, the seriousness of Swat Operation, called Operation Rah-e-Rast (The Righteous Way) was duly acknowledged, along with criticism about the overall strategy of the State to fight terrorism:

Rah-e-Rast was conducted more seriously than other operations, with the capture of a number of high-level militants. Taliban members were said to be leaving their positions and fleeing, with a number of top commanders arrested, although Fazlullah still seems to be at large. Commitment and morale were running high. The average

\footnotetext{
${ }^{34}$ Samir Puri, Pakistan's War on Terrorism: Strategies for Combating Jihadist Armed Groups Since 9/11 (London: Routledge, 2012), 97.

${ }^{35}$ C. Christine Fair and Seth G. Jones, "Pakistan's War Within," Survival: Global Politics \& Strategy 51, no. 6 (2009): 161-188, https://doi.org/10.1080/00396330903465204.
} 
officer-to-soldier ratio in combat fatalities during conventional operations is around 1:17 in most armies, while in Swat operations it has been $1: 5$ to $1: 6 .^{36}$

In the wake of this Operation, much needed stability would have returned to Swat if the political government and civil administration had built sufficient capacity over the years to gradually takeover the responsibilities of governance. This did not happen as quickly as required, resulting in a protracted stabilisation phase. In contrast to counterterrorism needs, the civilian government's law enforcement capacity in surveillance, policing, investigation, prosecution, adjudication and imprisonment remained insufficient, as was the situation elsewhere in the country. ${ }^{37}$

The trial of a large number of detainees of the Swat operation posed a great challenge for the stability of the area, because the witnesses were scared, the form of evidence required was scanty and criminal laws were incompatible with the conflict situation. It was arguably a negative effect of this unified effort. Redemption was sought by the political Government in promulgating new, compatible laws that were, in turn, criticised for highhandedness and in contravention to the Constitution. ${ }^{38}$

The post-conflict stabilisation phase remained beset by another controversy - how much longer should the military stay in Malakand was it the military's disinclination or civil administration's ineptitude that prevented the drawdown? The high social and economic cost of conflict left deep scars on the fabric of society which had severe impact on the post-war rehabilitation efforts. ${ }^{39}$ The dominant narrative of the Taliban, promoting rebellion against the elite-led exploitative social system, still needed to be countered. The tussle of narratives between the waning radical, socialistic, Taliban ideology, and the reviving pluralistic,

\footnotetext{
${ }^{36}$ Syed Manzar Abbas Zaidi, "Pakistan's Anti-Taliban Counter Insurgency," The RUSI Journal 155, no. 1 (2010): 10-19, https://doi.org/10.1080/03071841003683377.

37 Ibid.

38 ICG, Pakistan: Countering Militancy in PATA, report no. 242 (Brussels: International Crisis Group, 2013), 11-21, http://www.crisisgroup.org/ /media/Files/asia/southasia/pakistan/242-pakistan-countering-militancy-in-pata.pdf.

39 ICG, Pakistan: Countering Militancy in PATA, 24.
} 
'Whole-of-Nation' Approach and its Impacts:

Case of the 2009 Swat Crisis in Pakistan

capitalistic ideology was an important feature of the stabilisation phase in Malakand operations.

During the conflict, opinions abound that 'use of force may be necessary to forestall terrorist attacks or apprehend them wherever possible, but the use of force will be effective only if it is used as part of a strategy which also deals with underlying causes. ${ }^{40}$ The underlying causes were the lack of mutual trust between the state and the people reflected in absence of a reliable social, political and judicial system. The breeding grounds of terrorism, i.e., politically charged resentment given how religion was being manipulated, needed to be addressed as part of the overall strategy, without which the military effort would remain a wasteful and counterproductive activity.

\section{Lessons Learnt and Recommendations to Strengthen 'Whole- of-Nation' Approach}

The counterterrorism operation in Malakand, followed by the stabilisation achieved thereafter, is a vital antiterrorism success story of recent times. In comparison, the prolonged stalemate in Afghanistan, the US defeat in the aftermath of the 2013 Iraq invasion, the resultant creation of the Islamic State (IS), and the ongoing struggle against IS affiliates are some of the failed contemporary counterterrorism campaigns. The lands overtaken by the terrorists in Swat were reclaimed by use of force with minimum collateral damage, at a high moral pitch, and the displaced people were rehabilitated in a classic 'whole-of-nation' approach.

The events leading to the rise of Taliban's influence in Swat, defeat of terrorism, re-establishment of the writ of the State, high spirit of the affected population and restoration of people's confidence in the Government offer many lessons. The lessons will be discussed under five thematic areas, as developed by Hooker and Collins in Lessons Encountered: Learning from the Long War: national level decision-

\footnotetext{
${ }^{40}$ Zahid Anwar, "The Rise and Fall of Insurgency in North West Pakistan," Journal of the Research Society of Pakistan 48, no. 1 (2011): 1-20, http://pu.edu.pk/images/journal/history/PDF-FILES/zahid.pdf.
}

IPRI JOURNAL - WINTER 2019 
making (civil - military relations); unity of effort/ unity of command; intelligence and strategic appraisal; character of contemporary conflict; and security force assistance. This analysis framework, based on lessons learnt from the US' counterterrorism experiences in Afghanistan (Operation Enduring Freedom) and Iraq (Operation Iraqi Freedom) is pertinent for Pakistan's counterterrorism operations in Swat.

The first frame, national level decision-making, is important because 'strategic lessons begin with decision-making, which here entails efforts at shaping goals, developing strategies, crafting plans at the national and departmental levels, and developing ways to carry out those plans.' The authors argue in favour of civilian ownership of the policy process, as well as the military's duty to 'provide their military expertise and, if necessary, their respectful dissent to help prevent strategic disaster. ${ }^{41}$

The second frame, unity of effort / unity of command, is significant as 'the best strategic decisions exemplify unity of command on the military side and unity of effort in all areas.' In irregular conflicts 'wholeof-government efforts are essential,' and the 'military must improve its efforts to reach across departmental divide. ${ }^{42}$ However, it is important to draw distinction between the US' expeditionary Afghanistan and Iraq campaigns seeking galvanised governments, both intervening and local, vis-à-vis Pakistan's national campaign in Swat seeking a galvanised nation.

The third frame, intelligence and understanding the operational environment, is important due to the inherent problems with war intelligence and because:

Not only are understanding, analysis, and prediction difficult, but the thinking enemy also attempts to deceive us at every twist and turn. ${ }^{43}$

\footnotetext{
${ }^{41}$ Richard D. Hooker, Jr., and Joseph J. Collins, eds., Lessons Encountered: Learning from the Long War (Washington, D.C.: National Defense University Press, 2015), 7, https://ndupress.ndu.edu/Portals/68/Documents/Books/lessons-encountered/lessonsencountered.pdf.

${ }^{42}$ Ibid., 9.

${ }^{43}$ Ibid., 11.
} 
The fourth frame, character of contemporary conflict, though discussed from an expeditionary lens by Hooker and Collins, is still applicable to Swat because some of the sub-themes developed by the authors in this frame are relevant, like the post-conflict environment, battlefield learning, foreign terrorist sanctuaries, and strategic communications.

Again, in spite of being expeditionary in character, a part of the fifth frame, i.e., security force assistance, which deals with law enforcement and building capacity of the local security forces by way of military assistance, is relevant. ${ }^{44}$

\section{Civil-Military Relations}

The tactful creation of political space by the country's leadership, despite historically tumultuous civil-military relations, provided the key to successful national level decision-making. All self-serving agendas were shunned, dogmatic baggage was set aside, political divisions were bridged and an ideal civil-military equation was deliberately evolved. At the time of rising terrorism in Malakand area, Pakistan was slowly getting back on the track of unrestrained democracy with a new political government of PPP - a left of centre, progressive and popular political party, which came to power in February 2008 riding a sympathy wave due to the assassination of the party's leader and two-time Prime Minister of Pakistan, Benazir Bhutto by a Taliban gunman in a political rally just before the elections. President Zardari, Bhutto's husband, who took over the reins of PPP after his wife's death, and General Kayani, then-Chief of Army Staff (COAS), nurtured a conducive civil-military relationship that significantly helped to steer national decision-making during the terrorism crisis in Malakand. The ANP government in Khyber Pakhtunkhwa was also left of centre, which had come to power after decisively defeating the right-wing MMA in the province, promising peaceful reversal of rising radicalism.

\footnotetext{
${ }^{44}$ Ibid., 13-15.
} 
After these political forces tried their best to tackle militant radicalism through negotiations and pacts, the decision to use the military offensive in Malakand was taken unanimously in March 2009. Thereafter, the Army was given strategic guidance for restoring the writ of the State: eliminating the Taliban from the area; evacuating the local population to avoid collateral damage; and creating conditions for peaceful rehabilitation in a secure environment. The Army translated this strategic guidance into a workable action plan, and had the confidence of the federal and provincial governments during its implementation.

A conducive civil-military relationship, during and after the use of dominant kinetic force in counterterrorism, is the key to success in such interventions. It hinges upon: the military's acceptance of political authority; the political authority's confidence in the military's ability; the military's liberty of action within given constraints; civil-military combined assessment of the operational environment; and peoples' confidence in the concord of civil-military actions. In case of foreign forces intervention, the civil-military equation is more complex. It involves the intervening foreign government and military, alongside the host nation's government and military. In such cases, the four stakeholders have to be wedded together in a common decision-making framework, which is robust enough to prevent them from misperceiving or misrepresenting the actions of the other. Confidence of the people of the host nation and the intervening nation in this decision-making framework would represent the measure of success of the intervention and stabilisation effort.

\section{Unity of Effort/ Unity of Command}

The 'whole-of-nation' approach crafted by the Government and implemented by the military, civil administration, political parties and the population created unity of effort. Later, the deference shown to the political leadership by the military during and after the operations, and the confidence reposed by the political leadership in the operations preserved unity of command. 
A subtle effort was undertaken by the provincial and federal governments to mobilise nation-wide opinion and gain confidence of the Swat's population, needed for the subsequent success of direct military action. The Armed Forces' public relations department, Inter Services Public Relations (ISPR) kept the media engaged to project a 'regained paradise. ${ }^{45}$ An IDPs management organisation, Special Support Group (SSG), was created by the then-Prime Minister Gilani urgently under the Army's command with assistance from the federal and provincial governments. ${ }^{46}$ It planned and managed the task of registering IDPs, setting up IDP relief camps, disbursing monetary grants and instituting an electronically disbursable stipend for the IDPs while always remaining wary of three undercurrents: fake registrations, terrorists mixing in the IDP crowds and public perceptions about management of IDPs. During this phase, development of infrastructure was jointly undertaken by the Army and the Provincial/District administration, like setting up of Relief Providing Zones (RPZ) near the operation area in neighbouring districts of Mardan, Charsadda, Nowshera, Swabi, Peshawar, and even in southern districts like Tank and Dera Ismail Khan. ${ }^{47}$ Numerous international humanitarian initiatives like the Crisis Prevention and Recovery (CPR) project of the United Nations Development Program (UNDP) with the assistance of the European Union (EU), Japan, and Saudi Arabia for the IDPs were implemented. ${ }^{48}$

Under the Army's management and the civil government's stewardship, a well-balanced unity of effort and unity of command equilibrium was maintained throughout the kinetic and stabilisation phases. A culture of trust between national institutions like the country's Chief Executive, the Cabinet, Parliament, major political parties, the civil

${ }^{45}$ Reza Jan, "Paradise Regained: Swat One Year On," Critical Threats (blog), May 25, 2010, https://www.criticalthreats.org/analysis/paradise-regained-swat-one-year-on.

${ }^{46}$ Ahmed, "Coin in Peace-Building: Case Study of the 2009 Malakand Operation."

${ }^{47}$ Ibid.

${ }^{48}$ Aadil Mansoor, "Refugee Affected and Hosting Areas Programme," United Nations Development Programme in Pakistan, September 2009, accessed January 29, 2016, http://www.pk.undp.org/content/pakistan/en/home/operations/projects/crisis_prevention _and_recovery/refugee-affected-and-hosting-areas-programme.html. 
bureaucracy and military is key to winning the nation's confidence leading to a holistic 'whole-of-nation' approach for counterterrorism and stabilisation scenarios. In case of foreign interventions, winning this trust at home, in the intervened nation and internationally is vital and which is invariably difficult as seen in the Iraq and Afghanistan wars.

\section{Intelligence and Strategic Appraisal}

The importance of Taliban's actions and the danger they posed at the local level was understood, but their subsequent strategy of melting away to other sanctuaries and 'living to fight another day' was not fully appreciated. In Swat and adjoining areas, the need of eliminating the Taliban's influence and restoring people's confidence in the government was carefully determined. However, complete annihilation of the Taliban fighters in Swat was not possible due to: the restrained manner in which military force was being used against them to avoid collateral damage; availability of ample escape routes; and ability to hide within the population. Success, at the tactical and operational levels, could not be pursued at the strategic level due to multiple reasons. The hard earned public goodwill could not be utilised to maintain the counterterrorism momentum in pursuit of the fleeing terrorists in the troubled agencies of FATA. Later, the threat expanded as a result of Malakand operation and 'ballooned' into North Waziristan, South Waziristan, Khyber and Orakzai agencies of the erstwhile FATA, which could not be dealt with the same decisiveness due to consolidation efforts going on in Malakand, including extensive security assistance efforts to prevent resurgence. While at the same time, Operation Rah-e-Nijat (Path to Deliverance) was also being pursued in South Waziristan demanding sustained efforts. ${ }^{49}$ The militants took advantage of these simultaneous developments in Malakand and South Waziristan to reinforce their existing fronts in North Waziristan and Khyber agency, which were eventually cleared in 2014-17 during another

\footnotetext{
${ }^{49}$ Preceded by a three-month blockade, the military launched a massive operation between October and December 2009 in the TTP commander Baitullah Mehsud's heartland in South Waziristan, which was called Operation Rah-e-Nijat.
} 
'Whole-of-Nation' Approach and its Impacts:

Case of the 2009 Swat Crisis in Pakistan

series of daunting Operations called Zarb-e-Azb (Decisive Strike) ${ }^{50}$ This was followed by another series of operations, Radd-ul-Fasaad (Eradication of Tumult) against the terrorists hidden incognito in different parts of the country, which began in February 2017 and continues thus far. Hence, appraisal of the 'ballooning' counterterrorism requirements in order to balance the security needs of operational and tactical levels, is a strategic imperative.

Scenario-building for future nebulous terrorism threats, pervading in wide and loosely governed spaces, is only possible through a nationally coordinated intelligence effort. A strategic intelligence perspective on terrorism should include predictions about intra-terrorist linkages, transnational support, public perceptions, corruption and mismanagement in public affairs and terrorists' financial mechanisms. In case of foreign interventions, this is perhaps the most challenging domain due to absence of heuristic knowledge. Cultivating reliable local sources within and outside the host nation's government and military may help, but still remains fraught with risk.

\section{Character of Contemporary Conflict}

Political grievances and poor governance fuelled economic tensions that gave rise to social conflict, with in-fighting being the predominant characteristic. The twin challenge of controlling minds and territory defined the character of conflict in the Swat crisis. The enemy, though on the run, tried hard to encroach amorphously upon both - the territory by unrecognisable presence and the minds by instilling fear of reprisals. This war amongst people was waged to dig out both: fear from the minds and miscreants from the affected territory, while keeping public opinion favourable.

Clausewitz' remark about the first and foremost job of the political master and the military commander understanding the kind of war they are

\footnotetext{
${ }^{50}$ For details, see, Saman Zulfiqar, “An Overview of Pakistan's Security Situation after Operation Zarb-e-Azb,” Journal of Current Affairs 2, no. 1 (2017): 116-136, http://www.ipripak.org/wp-content/uploads/2017/10/art6szj21.pdf.
}

IPRI JOURNAL — WINTER 2019 
embarking upon is quintessentially applicable to the challenges of irregular warfare:

The first, the supreme, the most far-reaching act of judgement that the statesman and commander have to make is to establish by that test the kind of war on which they are embarking; neither mistaking it for, nor trying to turn it into, something that is alien to its nature. ${ }^{51}$

The Malakand operations offer clarity about the kind of war posed by the Taliban in the diplomatic, informational, military and economic domains. The threats in each one of those domains was dealt with separately. Developmental assistance was sought from friendly countries and international agencies to support the stabilisation phase. The narrative about the righteousness of the desired end-state and the ways and means employed was developed. The military operation was tuned to the requirement of selective and intelligence-based use of kinetic force to minimise collateral damage, always keeping wider public support in mind. The revival of the area's economy and administrative machinery was pursued at the best possible pace.

\section{Security Force Assistance}

Revival of the police, judiciary, intelligence and administration at the local level needs to be planned and resourced well before any counterterrorism operation actually begins. Security force assistance requirements tend to expand and extend, which need to be catered for in the planning phase. Any prolonged political disturbance, like in Swat, which deteriorates to the extent where counterterrorism effort becomes necessary, will demand prolonged security assistance to regain stability. In areas with deeper and longer history of loose governance protocols, longterm security assistance during the stabilisation phase would often be a much more serious imperative than the demands of the kinetic phase.

${ }^{51}$ Carl von Clausewitz, On War, ed. and trans. Michael Eliot Howard and Peter Paret (New Jersey: Princeton University, 1976), 88. 
'Whole-of-Nation' Approach and its Impacts:

Case of the 2009 Swat Crisis in Pakistan

\section{Conclusion}

An overview of the 'whole-of-nation' approach in Swat provides lessons for future leaders confronted with terrorism engulfing a peaceful area and its unsuspecting population. The important ones include: making consensual national level decisions; maintaining unity of effort and command; appraising dynamics of the strategic environment and understanding the evolving character of intrastate conflicts. The consensus in national level decisions comes from stakeholders strengthening each other's hand in political, social, informational and military domains. The unity of effort and command is born out of a common understanding about the gravity and nature of the threat, which in Pakistan's case led its federal, provincial and military establishments to adjust their spheres of influence in a manner that allowed uninterrupted operational control in Malakand by the Pakistan Army. In a nutshell, if the Malakand operation was to be described in one word, it would be 'trust' - trust of the people in the Government, of the Government in the military and of the international community in Pakistan.

IPRI JOURNAL — WINTER 2019 